\title{
IMPACTS OF FISH MEAL REPLACEMENT WITH FERMENTED ANIMAL BY- PRODUCTS IN AFRICAN CATFISH (CLARIAS GARIEPINUS) DIETS ON GROWTH, BODY COMPOSITION, AND FISH QUALITY
}

\author{
EMAN H. EL-SAYED ${ }^{1}$; AZZA S. EL-DEMERDASH ${ }^{1}$; AMINA M. ELAMIN ${ }^{1}$ and \\ MOHAMED S. YUSUF ${ }^{2}$ \\ ${ }^{1}$ Animal Health Research Institute, Zagazig, Egypt \\ ${ }^{2}$ Faculty of Veterinary Medicine, Suez Canal University, Ismailia, Egypt
}

Received: 5 December 2019; Accepted: 29 December 2019

\begin{abstract}
This study was conducted to evaluate the effect of partial substitution of fish-meal (FM) with two types of fermented animal by-products (fish and poultry offal's wastes) on growth performance, microbiological, and fish quality of African catfish (Clarias gariepinus). Fish offal's silage (FOS) and poultry offal's silage (POS) were fermented by Lactobacillus acidophilus. Five isonitrogenous (34.3\% crude protein) diets were formulated to comprise two levels of fermented fish offal $(20 \%$ and $40 \%)$, two levels of fermented poultry offal (20\% and $40 \%$ ) wastes, and $100 \%$ fish meal as a control. Ninety hatcheries bred African catfish were randomly distributed into 5 equal groups every 18 fish in three replicate (6 fish/ replicate aquaria). Each of the diets was fed to triplicate groups of African catfish with mean initial weight (MIW) $52 \mathrm{~g} \pm 0.01$ at $5 \%$ body weight in glass aquaria $(30 \times 30 \times 70 \mathrm{~cm})$ twice daily (morning and evening) for 12 weeks. The results showed that fish in the fourth group fed on diet supplemented with $20 \%$ POS recorded the best feed conversion ratio (FCR) (1.77 \pm 0.1$)$,

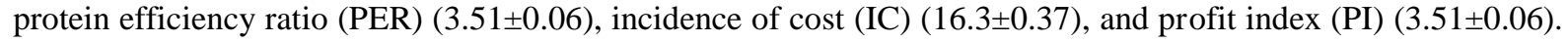
Fish in group four as well had the least total bacterial count, coliform, and mold \& yeast. The least lactic acid bacteria count and the best overall acceptance were detected also in the fourth group as compared to other groups except diet 1(control) which means it can be used safely without significantly affecting public health or consumer acceptance.
\end{abstract}

Keywords: Fish-meal replacement, Growth performance, Cost efficiency, Microbial count, organoleptic parameters.

\section{INTRODUCTION}

Fish meal (FM) has been used in aquafeeds for decades due to its high protein content, balanced amino acid profile, high digestibility, palatability and as a source of essential fatty acids. However, FM has currently become expensive as well as scarce due to its extensive use in animal and fish feed industries (Akegbejo-Samsons and Fasakin, 2008). Therefore, researchers are looking for other alternative protein sources that can lower the level of FM used in fish feed formulation without significantly affecting growth performance and fish quality and yet profitable. Two promising animal by-products used for replacement of FM are fish offal and poultry offal due to their high protein content, high level of lipid which may cause a protein-sparing effect, low

Corresponding author: Dr. AZZA S. EL-DEMERDASH E-mail address: Dr.azzasalah@yahoo.com.

Present address: Animal Health Research Institute, Zagazig, Egypt carbohydrate content, and lack of anti-nutritional factors, but the use of animal by-products was also constrained by high moisture, indigestible particles, microbial contaminants, etc. (Cruz-Suárez et al., 2007; Samaddar and Kaviraj, 2014). Fermentation is an effective biotechnological tool that can be used to overcome many of the before mentioned problems associated with the utilization of animal by-products in fish diets that can reduce the cost of aquafeeds and protect the environment from microbial contamination related to the disposal of animal wastes. Fermentation also improved the nutritional quality and digestibility of the ingredients (Vidotti et al., 2003). Lactic acid bacteria (LAB) were widely employed in fermentation for animal feed production (Driehuis et al., 2001, Samaddar and Kaviraj, 2014 and Zhao et al., 2019). Moreover, it is a simpler, faster, eco-friendlier, and economical process (Ahmed and Mahendrakar, 1996, Raghunath and Gopakumar, 2002).

Therefore, the current study was conducted to investigate the effect of partial replacement of FM with fermented fish fermented offal's silage and 
poultry offal's silage on growth performance, microbiological and organoleptic fish quality of African catfish (Clarias gariepinus).

\section{MATERIALS AND METHODS}

\section{Experimental fish}

Ninety hatcheries bred African catfish (Clarias gariepinus) (mean initial weight $52 \pm 0.01 \mathrm{~g}$ ) were obtained from the Central laboratory for aquaculture research (CLAR) at Abbassa, Abou-Hammad, Sharkia-Egypt. Fish were transported to the laboratory at Nutrition and Clinical Nutrition Department, Faculty of Veterinary Medicine, Suez Canal University. Upon arrival, all fish were treated with a solution of $3 \% \mathrm{NaCl}$ for 15 min to eliminate ectoparasites infection, acclimated to the experimental conditions for one week and fed the control diet $(100 \%$ FM). Hatchery bred African catfish were randomly distributed into 5 groups each of 18 fish in three replicates (6 fish/ replicate aquaria)

\section{Fermentation}

Samples of fish offal (comprising mainly heads and intestine of tilapia fishes and mullets) and samples of poultry offal were collected from the local fish market in Ismailia province, transported in ice buckets to avoid further contamination to the laboratory and stored at $-20^{\circ} \mathrm{C}$ before processing. Cane molasses also, collected from the local market was used as a source of fermentable carbohydrate for microorganisms involved in the fermentation.

Five kilograms of fish offal and poultry offal samples each were weighed and thoroughly rinsed in tap water before blended into a paste. Fifty $\mathrm{ml} / \mathrm{kg}$ of actively growing culture of Lactobacillus acidophilus and $150 \mathrm{~g} / \mathrm{kg}$ of cane molasses were added to the paste and allowed to ferment for 14 days in airtight plastic containers. The $\mathrm{pH}$ of the silage dropped from the initial value of 7.4 to 4.12 on the 14th day from the start of the fermentation process. The desired level of $\mathrm{pH}$ indicative of completion of fermentation is $4.0-$ 4.2 indicates that the fermented products are safe from spoilage and fit for use as a feedstuff for animals (Lee et al., 2003; Hashoda et al., 2001). The liquid product was then oven-dried at $60^{\circ} \mathrm{C}$ for $48 \mathrm{~h}$. The dried product was ground into fine powder to form the silage meal, and stored at $-20^{\circ} \mathrm{C}$.

\section{Feed formulation}

Five isonitrogenous ( $34.3 \%$ crude protein) diets were formulated by replacing dietary fish meal at $20 \%$, $40 \%$ with fermented fish offal's silage, $20 \%, 40 \%$ fermented poultry offal's silage a and control diet $(100 \%$ fish meal) was also formulated. The ingredients of each diet were mixed thoroughly at the required ratios (Table 1) in Braun mixing machine to obtain a homogeneous mass. Corn starch and hot water were added and mixed further to obtain a dough-like paste. The diets mixtures were then passed through a 2-mm die (Braun) mincing machine to form model-like strands that were air-dried and stored at $20^{\circ} \mathrm{C}$ in air-tight polyethylene bags. The strands were mechanically broken before feeding into pellets of a suitable size for African catfish (Clarias gariepinus).

\section{Experimental design}

At the start of the experiment, 15 glass aquaria (40 X $45 \times 80 \mathrm{Cm}$ ) were each stocked with 6 fish with an average weight of $52 \pm 0.01 \mathrm{~g}$. Each diet was assigned to triplicate groups of fish. Fish were fed at a rate of $5 \%$ of its body weight, divided into two equal feedings (morning and evening). Fish from each aquarium were weighed collectively every two weeks and the amount of diet fed was adjusted accordingly.

\section{Sampling and analysis}

\section{Proximate analysis}

Proximate analysis of random samples of fish offal's silage and poultry offal silage was carried out according to AOAC, 1990. Data obtained were used in the feed formulation of experimental diets as shown in Table 2.

\section{Growth performance}

At the end of the feeding trial, fish were starved for 24 hours, counted and weighed. The obtained data were used in growth performance calculations:

Total body weight gain $=$ Final body weight $(\mathrm{g})-$ Initial body weight $(\mathrm{g})$

Feed conversion ratio $\mathrm{FCR}=$ feed intake $(\mathrm{g}) /$ body weight gain $(\mathrm{g})$

Protein efficiency ratio PER = Protein intake $(\mathrm{g}) /$ body weight gain $(\mathrm{g})$

\section{Economic analysis}

Economic analysis was carried out to estimate the cost of feed to raise a kilogram of fish using the experimental diets:

Incidence of cost $\mathrm{IC}=$ cost of feed/weight gain Profit index PI = Value of fish $/$ Cost of feed

\section{Microbiological}

Three random samples of fish from each experimental group were taken. Ten grams of each sample were mixed with $90 \mathrm{ml}$ of sterile buffered $0.1 \%$ peptone water in a sterile blender, under sterile conditions, to give $1 / 10$ dilution. Serial dilutions were prepared to be used for counting total bacteria count, total coliform count, Salmonella, Lactobacillus, Staphylococci, yeast, and mold counts according to the procedures described by (Manual, 1984). 


\section{Organoleptic assessment}

Three random samples of fish from each experimental group were filleted fillets rinsed with cold water then 2 fillets (average weight $20 \mathrm{~g}$ ) were cut from the central portion, placed in individual covered foil dishes and held at $5^{\circ} \mathrm{C}$ until removed to room temp $24^{\circ} \mathrm{C}$ to equilibrate for $1 \mathrm{~h}$. before cooking. Samples were placed on trays, cooked in an electric oven at $200^{\circ} \mathrm{C}$ for $6 \mathrm{~min}$. then transferred to a holding oven at $75^{\circ} \mathrm{C}$ for up to half an hour before tasting. Ten panelists were evaluated for taste, odor, texture, appearance and overall acceptability. The assessment was based on the scoring system by Minim, (2006) which involved the measurement of the previously mentioned parameters on a 7-point hedonic scale for the determination of selected characteristics. The seven categories were ranked as follows: very much liked (7), liked a lot (6), liked (5) liked and didn't liked (4), disliked (3), much disliked (2) and very much disliked (1).

\section{Statistical analysis}

Data are presented as treatment means \pm S. E. The data were analyzed by one-way ANOVA. When ANOVA identified differences among groups, multiple comparisons among means were made with Duncan's multiple ranges tests. Statistical significance was determined by setting the aggregate type I error at 5\% (P<0.05) for each set of comparisons. All the calculations were carried out using the statistical package SPSS version 14 for windows.

Table 1 Proximate composition of fermented fish offal's silage and poultry offal's silage (air-dried sample)

\begin{tabular}{ccc}
\hline Nutrient $(\boldsymbol{\%})$ & fish offal's silage & poultry offal's silage \\
\hline Moisture & $76.4 \pm 0.8$ & $66.3 \pm 0.4$ \\
\hline Crude Protein & $35.2 \pm 0.7$ & $41.7 \pm 0.7$ \\
\hline Ether Extract & $7.9 \pm 1.3$ & $24.8 \pm 1.1$ \\
\hline Ash & $8.6 \pm 0.2$ & $6.3 \pm 0.3$ \\
\hline
\end{tabular}

Table 2: Dietary composition of experimental diets according to recommendations of (NRC, 2011).

\begin{tabular}{|c|c|c|c|c|c|}
\hline Ingredient \% & $\begin{array}{c}\text { Diet } 1 \\
\text { (control) }\end{array}$ & $\begin{array}{c}\text { Diet } 2 \\
(20 \% \text { FOS })\end{array}$ & $\begin{array}{c}\text { Diet } 3 \\
(40 \% \text { FOS })\end{array}$ & $\begin{array}{c}\text { Diet } 4 \\
(20 \% \text { POS })\end{array}$ & $\begin{array}{l}\text { Diet } 5 \\
(40 \% \\
\text { POS) } \\
\end{array}$ \\
\hline Poultry meal (66\%) & 19.4 & 19.7 & 20.3 & 19.5 & 20 \\
\hline Fish meal $(61.6 \%)$ & 10 & 8 & 6 & 8 & 6 \\
\hline Poultry offal's silage $(41.7 \%)$ & 0.0 & 0.0 & 0.0 & 2 & 4 \\
\hline Fish offal's silage (35.2\%) & 0.0 & 2 & 4 & 0.0 & 0.0 \\
\hline Ground Y. Corn (8.7\%) & 21.1 & 19.8 & 18.8 & 19.7 & 19 \\
\hline Soybean meal $(41.6 \%)$ & 26.5 & 27.6 & 28.1 & 27.7 & 28 \\
\hline Wheat middling (17.1\%) & 15 & 14.6 & 14.5 & 15 & 15 \\
\hline \# Oil mix & 6 & 6.1 & 6.1 & 6.1 & 6 \\
\hline *Premix (Vit. \& Min.) & 0.3 & 0.3 & 0.3 & 0.3 & 0.3 \\
\hline Common salt & 0.3 & 0.3 & 0.3 & 0.3 & 0.3 \\
\hline Mono calcium phosphate & 1.4 & 1.6 & 1.6 & 1.4 & 1.4 \\
\hline Crude protein (\%) & $34.3 \pm 0.7$ & $34.3 \pm 0.8$ & $34.3 \pm 0.4$ & $34.3 \pm 1.3$ & $34.3 \pm 1.6$ \\
\hline Digestible energy & $\begin{array}{c}2950 \mathrm{Kcal} \\
\mathrm{DE} / \mathrm{kg}\end{array}$ & $\begin{array}{c}2950 \mathrm{Kcal} \\
\mathrm{DE} / \mathrm{kg}\end{array}$ & $\begin{array}{c}2950 \mathrm{Kcal} \\
\mathrm{DE} / \mathrm{kg}\end{array}$ & $\begin{array}{c}2950 \mathrm{Kcal} \\
\mathrm{DE} / \mathrm{kg}\end{array}$ & $\begin{array}{c}2950 \mathrm{Kcal} \\
\mathrm{DE} / \mathrm{kg}\end{array}$ \\
\hline
\end{tabular}

*Premix, each $3 \mathrm{~kg}$ contains the following vitamins, minerals, monocalcium phosphate, binder and salt: "Vit.A 15 MIU, Vit. D3 2 MIU, Vit. E 1,000 mg, Vit. k3 1,000 mg, Vit. B11,000 mg, Vit. B2 5,000 mg, Vit. B6 1,500 mg, Vit. B12 10 mg, biotin50 mg, pantothenic acid 10,000 mg, nicotinic acid 30,000 mg, folic acid1,000 mg, manganese 60,000 mg, zinc 50,000 $\mathrm{mg}$, iron 30,000 mg, copper 4,000 mg, iodine $300 \mathrm{mg}$, selenium $100 \mathrm{mg}$, cobalt $100 \mathrm{mg}$ ", carrier (CaCO3) to $3 \mathrm{~kg}$ (Golden premix, Egypt).

\# linseed oil plus olein (1:1).

The analysis was performed according to the Official Methods of Analytical Association of Official Analytical Chemists, Arlington (AOAC, 1990) 


\section{RESULTS}

Growth performance data (Table 3 and Figure 1) showed that there were significant differences $(\mathrm{P}<$ 0.05 ) between groups in the final average weight of fish (FW) and weight gain (WG) at the end of the 12 weeks feeding trial. Fish in the fifth group (40\% POS) recorded the highest FW and WG compared to other groups but lower than the control one, while both $20 \%$ POS and $20 \%$ FOS supplemented groups recorded the same value. Fish in $40 \%$ FOS supplemented group recorded the lowest value. There were significant differences $(\mathrm{P}<0.05)$ between experimental groups in feed conversion ratio (FCR) where fish in fifth and third groups recorded the worst values compared to the control group and the other treated groups. The best values were recorded in both the control and fourth (POS 20\%) groups.

Regarding the cost evaluation data in Table 4, the profit index (IP) obtained by using the diets was highest in the third group (40\% FOS) as compared to the control group which recorded the lowest value. The highest incidence of the cost was found in the fifth group (40\% POS) compared with the control group which was the lowest.
Microbiological data (Table 5) showed that at the end of the feeding trial, there were significant differences $(\mathrm{P}<0.05)$ in total bacterial count between groups where FOS $40 \%$ supplemented group recorded the highest value followed by the control group and POS $40 \%$ group, while POS $20 \%$ and FOS $20 \%$ groups recorded the lowest value. Almost the same results were obtained in coliform bacteria. There were no significant differences between groups in Staphylococcus. Salmonella was not detected in all 5 groups. For Mold and Yeast results, FOS $40 \%$ and POS $20 \%$ recorded the highest value followed by POS $40 \%$ while both POS $20 \%$ and the control group recorded the lowest value.

Organoleptic parameter data (Table 6) showed that there were no significant differences $(\mathrm{P}<0.05)$ in color between all groups except FOS $40 \%$ group which recorded a lower value compared to other groups. Significant differences $(\mathrm{P}<0.05)$ between groups in taste and texture were detected where the control and POW 20\% recorded the highest value followed by FOW 20\% group while both FOW $40 \%$ and POW $40 \%$ groups recorded the lowest value. There were significant differences $(\mathrm{P}<0.05)$ between groups also in odor.

Table 3: Growth performance parameters of African catfish, Clarias gariepinus fed the experimental diets (means \pm S.E)

\begin{tabular}{cccccc}
\hline Parameter & $\begin{array}{c}\text { Diet 1 } \\
(\text { control })\end{array}$ & $\begin{array}{c}\text { Diet 2 } \\
(20 \% \text { FOS })\end{array}$ & $\begin{array}{c}\text { Diet 3 } \\
(40 \% \text { FOS })\end{array}$ & $\begin{array}{c}\text { Diet 4 } \\
(20 \% \text { POS })\end{array}$ & $\begin{array}{c}\text { Diet 5 } \\
(40 \% \text { POS })\end{array}$ \\
\hline Initial Wt. $(\mathrm{g})$ & $299.7 \pm 1.3$ & $304.7 \pm 4.2$ & $303.0 \pm 1.1$ & $301.0 \pm 1.3$ & $299.7 \pm 1.6$ \\
\hline Final Wt. $(\mathrm{g})$ & $440.3 \pm 4.6^{\mathrm{a}}$ & $389.7 \pm 1.6^{\mathrm{c}}$ & $374.7 \pm 1.3^{\mathrm{d}}$ & $385.3 \pm 3.6^{\mathrm{c}}$ & $410.7 \pm 3.1^{\mathrm{b}}$ \\
\hline Weight Gain $(\mathrm{g})$ & $140.6 \pm 3.3^{\mathrm{a}}$ & $85.0 \pm 4^{\mathrm{c}}$ & $64.6 \pm 1.3^{\mathrm{d}}$ & $84.3 \pm 7.2^{\mathrm{c}}$ & $111.0 \pm 2.1^{\mathrm{b}}$ \\
\hline Feed intake (g) & $245.8 \pm 2.7^{\mathrm{a}}$ & $167.2 \pm 7^{\mathrm{b}}$ & $136.3 \pm 1.3^{\mathrm{b}}$ & $149.2 \pm 6.5^{\mathrm{b}}$ & $246.9 \pm 8^{\mathrm{a}}$ \\
\hline FCR & $1.75 \pm 0.1^{\mathrm{cd}}$ & $2.0 \pm 0.1^{\mathrm{bc}}$ & $2.1 \pm 0.1^{\mathrm{ab}}$ & $1.77 \pm 0.1^{\mathrm{cd}}$ & $2.2 \pm 0.1^{\mathrm{ab}}$ \\
\hline PER & $1.67 \pm 0.01^{\mathrm{a}}$ & $1.48 \pm 0.00^{\mathrm{bc}}$ & $1.38 \pm 0.00^{\mathrm{c}}$ & $1.58 \pm 0.03^{\mathrm{ab}}$ & $1.24 \pm 0.06^{\mathrm{d}}$ \\
\hline
\end{tabular}

abc means in the same row with different superscripts are significantly different $(\mathrm{P}<0.05)$.

FCR: feed conversion ratio, PER: Protein efficiency ratio.

Table 4: Costs evaluation of experimental diets fed to African catfish, Clarias gariepinus (means \pm S.E).

\begin{tabular}{|c|c|c|c|c|c|}
\hline Value & $\begin{array}{c}\text { Diet } 1 \\
(\text { control })\end{array}$ & $\begin{array}{c}\text { Diet } 2 \\
(20 \% \text { FOS })\end{array}$ & $\begin{array}{c}\text { Diet } 3 \\
(40 \% \text { FOS }) \\
\end{array}$ & $\begin{array}{c}\text { Diet } 4 \\
(20 \% \text { POS }) \\
\end{array}$ & $\begin{array}{c}\text { Diet } 5 \\
(40 \% \text { POS }) \\
\end{array}$ \\
\hline Feed consumed $(\mathrm{g})$ & $245.8 \pm 2.7^{\mathrm{a}}$ & $167.2 \pm 7^{b}$ & $136.3 \pm 1.3^{b}$ & $149.2 \pm 6.5^{b}$ & $246.9 \pm 8^{\mathrm{a}}$ \\
\hline Weight gain $(\mathrm{g})$ & $140.6 \pm 3.3^{\mathrm{a}}$ & $85.0 \pm 4^{\mathrm{c}}$ & $64.6 \pm 1.3^{\mathrm{d}}$ & $84.3 \pm 7.2^{\mathrm{c}}$ & $111.0 \pm 2.1^{\mathrm{b}}$ \\
\hline Cost of feed (LE) & $2.26 \pm 0.01^{\mathrm{a}}$ & $1.48 \pm 0.03^{\mathrm{b}}$ & $1.15 \pm 0.01^{\mathrm{d}}$ & $1.37 \pm 0.03^{c}$ & $2.22 \pm 0.09^{\mathrm{a}}$ \\
\hline Value of fish (LE) & $5.28 \pm 0.02^{\mathrm{a}}$ & $4.76 \pm 0.01^{\mathrm{c}}$ & $4.49 \pm 0.01^{\mathrm{d}}$ & $4.62 \pm 0.03^{c}$ & $4.92 \pm 0.06^{\mathrm{b}}$ \\
\hline Incidence of cost $^{*}$ & $16.08 \pm 0.12^{c}$ & $17.43 \pm 0.05^{\mathrm{bc}}$ & $17.86 \pm 0.08^{b}$ & $16.30 \pm 0.37^{b c}$ & $19.79 \pm 1.04^{\mathrm{a}}$ \\
\hline Profit index** & $2.43 \pm 0.00^{\mathrm{d}}$ & $3.16 \pm 0.06^{c}$ & $3.89 \pm 0.01^{\mathrm{a}}$ & $3.51 \pm 0.06^{b}$ & $2.23 \pm 0.09^{\mathrm{d}}$ \\
\hline
\end{tabular}


Table 5: Microbial population of African catfish, Clarias gariepinus fed the experimental diets (means \pm S.E)

\begin{tabular}{cccccc}
\hline $\begin{array}{c}\text { Microorganism } \\
(\text { Log CFU/ml })\end{array}$ & $\begin{array}{c}\text { Diet 1 } \\
(\text { control })\end{array}$ & $\begin{array}{c}\text { Diet 2 } \\
(20 \% \text { FOS })\end{array}$ & $\begin{array}{c}\text { Diet 3 } \\
(40 \% \text { FOS })\end{array}$ & $\begin{array}{c}\text { Diet 4 } \\
(20 \% \text { POS })\end{array}$ & $\begin{array}{c}\text { Diet 5 } \\
(40 \% \text { POS })\end{array}$ \\
\hline Total bacterial count & $4.82 \pm 0.27^{\mathrm{bc}}$ & $4.27 \pm 0.18^{\mathrm{c}}$ & $5.44 \pm 0.35^{\mathrm{b}}$ & $4.12 \pm 0.18^{\mathrm{c}}$ & $5.03 \pm 0.39^{\mathrm{bc}}$ \\
\hline Coliform & $3.36 \pm 0.32^{\mathrm{bc}}$ & $3.65 \pm 0.10^{\mathrm{abc}}$ & $4.13 \pm 0.17^{\mathrm{a}}$ & $2.95 \pm 0.27^{\mathrm{c}}$ & $3.98 \pm 0.20^{\mathrm{ab}}$ \\
\hline Salmonella & $\mathrm{ND}$ & $\mathrm{ND}$ & $\mathrm{ND}$ & $\mathrm{ND}$ & ND \\
\hline Staphylococci & $4.36 \pm 0.27$ & $4.11 \pm 0.12$ & $4.31 \pm 0.19$ & $4.00 \pm 0.16$ & $4.27 \pm 0.30$ \\
\hline Mold \& yeast & $4.35 \pm 0.26^{\mathrm{bc}}$ & $5.06 \pm 0.20^{\mathrm{a}}$ & $5.47 \pm 0.16^{\mathrm{a}}$ & $3.76 \pm 0.23^{\mathrm{c}}$ & $4.86 \pm 0.22^{\mathrm{bc}}$ \\
\hline LAB & $1.71 \pm 0.11^{\mathrm{c}}$ & $3.28 \pm 0.35^{\mathrm{bc}}$ & $3.71 \pm 0.32^{\mathrm{a}}$ & $2.39 \pm 0.29^{\mathrm{bc}}$ & $3.11 \pm 0.31^{\mathrm{bc}}$ \\
\hline
\end{tabular}

abc means in the same row with different superscripts are significantly different $(\mathrm{P}<0.05)$.

LAB: Lactic acid bacteria, ND: Not detected.

Table 6: Organoleptic parameters of African catfish, Clarias gariepinus fed the experimental diets (means \pm S.E)

\begin{tabular}{cccccc}
\hline Physical parameters & $\begin{array}{c}\text { Diet 1 } \\
(\text { control })\end{array}$ & $\begin{array}{c}\text { Diet 2 } \\
(\mathbf{2 0 \%} \text { FOS })\end{array}$ & $\begin{array}{c}\text { Diet 3 } \\
(\mathbf{4 0 \%} \text { FOS })\end{array}$ & $\begin{array}{c}\text { Diet 4 } \\
(\mathbf{2 0 \%} \text { POS })\end{array}$ & $\begin{array}{c}\text { Diet 5 } \\
(40 \% \text { POS })\end{array}$ \\
\hline Taste & $6.66 \pm 0.33^{\mathrm{a}}$ & $5.83 \pm 0.16^{\mathrm{ab}}$ & $5.00 \pm 0.57^{\mathrm{b}}$ & $6.33 \pm 0.33^{\mathrm{a}}$ & $5.66 \pm 0.33^{\mathrm{b}}$ \\
\hline Odour & $6.83 \pm 0.16^{\mathrm{a}}$ & $5.00 \pm 0.57^{\mathrm{bc}}$ & $4.00 \pm 0.57^{\mathrm{c}}$ & $6.33 \pm 0.66^{\mathrm{ab}}$ & $5.56 \pm 0.33^{\mathrm{ab}}$ \\
\hline Texture & $6.33 \pm 0.33^{\mathrm{a}}$ & $5.00 \pm 0.57^{\mathrm{ab}}$ & $4.00 \pm 0.57^{\mathrm{b}}$ & $6.83 \pm 0.18^{\mathrm{a}}$ & $5.46 \pm 0.33^{\mathrm{b}}$ \\
\hline Appearance & $6.83 \pm 0.16^{\mathrm{a}}$ & $5.66 \pm 0.33^{\mathrm{b}}$ & $4.33 \pm 0.33^{\mathrm{c}}$ & $6.83 \pm 0.16^{\mathrm{a}}$ & $5.00 \pm 0.57^{\mathrm{bc}}$ \\
\hline Color & $6.50 \pm 0.28^{\mathrm{a}}$ & $5.33 \pm 0.33^{\mathrm{a}}$ & $4.00 \pm 0.57^{\mathrm{b}}$ & $6.00 \pm 0.28^{\mathrm{a}}$ & $5.33 \pm 0.33^{\mathrm{a}}$ \\
\hline Overall acceptability & $6.64 \pm 0.09^{\mathrm{a}}$ & $5.42 \pm 0.12^{\mathrm{b}}$ & $4.33 \pm 0.33^{\mathrm{c}}$ & $6.44 \pm 0.24^{\mathrm{ab}}$ & $5.38 \pm 0.05^{\mathrm{b}}$ \\
\hline
\end{tabular}

abc means in the same row with different superscripts are significantly different $(\mathrm{P}<0.05)$.

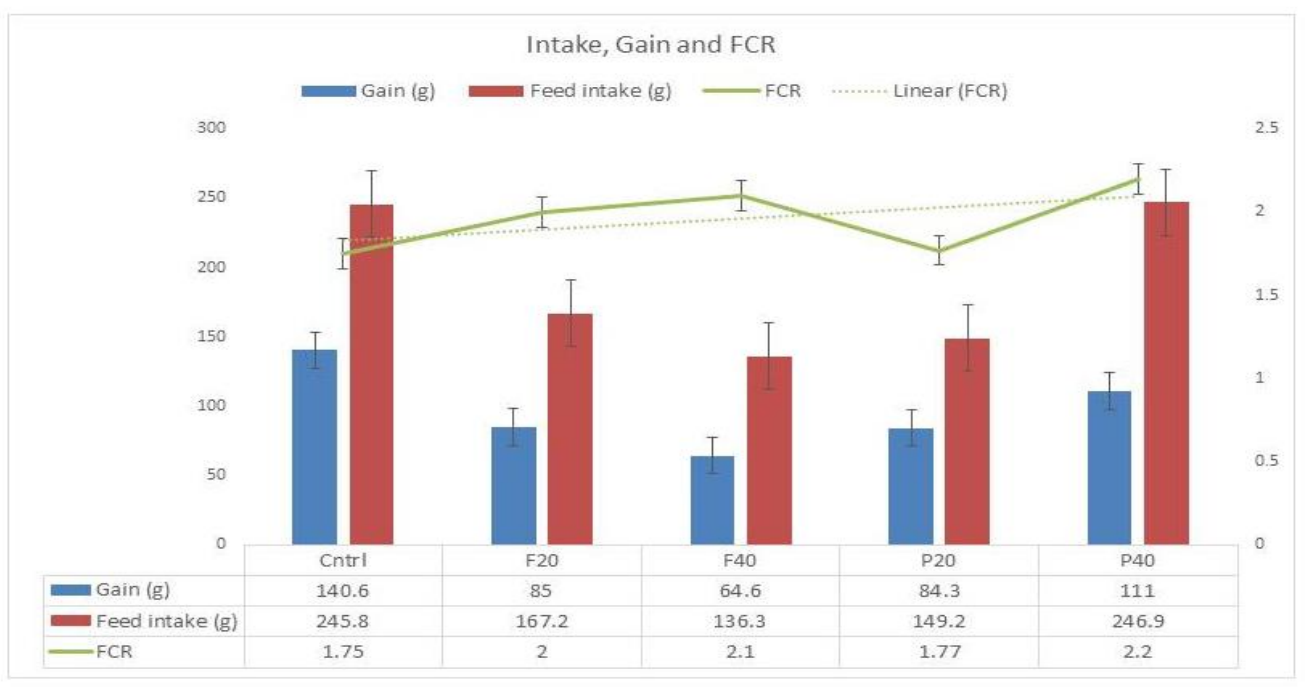

Figure 1 Feed intake, body weight gain and feed conversation ratio (FCR) relationship of African catfish fed the experimental diets. 


\section{DISCUSSION}

The proximate composition of bacterially fermented poultry offal's silage and fish offal's silage used in experimental diets formulation is shown in Table 1. Crude protein percent of poultry offal's silage $(41.7 \pm 0.7)$ and fish offal's silage $(35.2 \pm 0.7)$ showed that silage is rich in protein and compares favorably with other conventional dietary protein sources. Similar results were obtained by Soltan and Tharwat, (2006) who reported $32.51 \% \mathrm{CP}$ in fermented fish silage and Belal et al. (1995) who reported 39.5\% CP in chicken offal's silage.

Data of growth performance parameters (Table 3, Fig. 1) and production costs evaluation (Table 4) revealed that there were significant differences $(\mathrm{P}<0.05)$ between groups in FW, WG, FI, FCR and PER were fish in control group recorded the best growth and feed utilization parameters and the least profit index (PI). The high digestibility, palatability and the balanced amino acid profile of FM and its high price also, could explain the better growth performance and feed utilization of the control group, yet remains costly. Fish in the fourth group (20\% POS) recorded the highest FCR and PER and the best IC and PI as compared to the other treated groups except for the control group. Fermentation breaks down protein which facilitates nutrient utilization as fish can assimilate protein as amino acids and short peptides, hence the better performance (FCR, 1.77 and PER, 1.58) and consequently, the better IC and PI of diet 4 together with the level of inclusion (20\% POS). Similar results were obtained by Higgs (1979) who reported that at least $28 \%$ of poultry by-product meal may be included in the diet of Coho salmon, without amino acid supplementation and Tacon (1993) who reported that poultry by-products showed similarities with fishmeal based on the nutritional composition. Also, Steffens (1994) reported that poultry by-product meal is suitable as a partial or complete replacement, but that complete substitution required amino acid supplementation, principally with lysine and methionine. This could explain why diet 5 recorded the highest FW and WG compared to other groups but less than diet 1 and also the highest FI similar to diet 1 . However, it wasn't successful when it comes to feeding utilization FCR, IC, PI and PER which were the least among all experimental groups. Also, Fagbenro and Bello-Olusoji (1997) reported that poultry offal can replace up to $40 \%$ of a high-quality fishmeal protein without amino acid supplementation, whilst not compromising growth performance and feed utilization.

In contrast, Soltan and Tharwat (2006) reported a non-significant effect on growth and feed utilization parameters and reduced feed costs $/ \mathrm{kg}$ diet and feed costs $/ \mathrm{kg}$ weight gain by 15.59 and $19.39 \%$, respectively when a fish meal was replaced by $50 \%$ fermented fish silage. Our data showed that diet 2
(20\% FOS) recorded lower FCR, PER, IC, PI values than diet 4 (20\% POS) while, Higher FCR, PER and IC values than diet 3 (40\% FOS). Moreover, Mondal et al. (2008) reported that fermented fish offal could replace $30 \%$ of FM in diets of Labeo rohita and Heteropneustes fossilis.

The purpose of microbial population tests is to detect pathogenic bacteria (Salmonella, Staphylococcus aureus, E. coli) or indicator organisms of fecal pollution (fecal coliforms, fecal streptococci) or other types of general contamination or poor handling practices (coliform bacteria, faecal streptococci, total viable count). Organoleptic assessment is a sensory assessment using senses to judge the quality of a product. Both parameters are important in the aquaculture industry to ensure food safety and consumer acceptance.

Microbial population and organoleptic parameters of African catfish, Clarias gariepinus fed the experimental diets are shown in Table 5 and Table 6 . Statistical analysis of the obtained data revealed that there were significant differences $(\mathrm{P}<0.05)$ between groups in TBC, Coliform, Mold \& yeast and LAB where diet 4 recorded the least TBC, coliform and mold \& yeast as compared to all other groups, while the least LAB and overall acceptance as compared to the other groups except the control group. There were no significant differences between groups in staphylococcus count and salmonella was not detected in any of the groups. However, the highest degree of hazardous microorganisms (TBC, Coliform, Mold \& Yeast and LAB) was found in diet $3(40 \%$ FOS). The presence of these microorganisms in fish is of great concern to public health. Fish in the third group also recorded the lowest overall acceptance which might be quite understandable taking into consideration its high degree of contamination.

\section{CONCLUSION}

Based on nutrient utilization indices, estimated economic benefits, microbial count and overall acceptance, poultry offal's silage can effectively replace fishmeal in African catfish (Clarias gariepinus) diets till the level of $20 \%$ without affecting growth, microbial and organoleptic qualities for a profitable and sustainable aquaculture venture.

\section{CONFLICTS OF INTEREST}

The authors declare that there is no competing interest.

\section{REFERENCES}

Ahmed, J. and Mahendrakar, N.S. (1996): 'Autolysis and rancidity development in tropical freshwater fish viscera during fermentation', Bioresource Technology, 58(3), 247-251. 
Akegbejo-Samsons, Y. and Fasakin, A.E. (2008): 'Use of rendered animal protein meals as fish meal replacer in the diets of the African catfish, Clarias gariepinus (Burchell, 1822) juveniles', Sommaire/Inhoud/Sumario, 26(2), 89-92.

AOAC (1990): "“Association of Official Analytical Chemists"', 15th Ed., sections 973.31, 952.08, 937.09 Arlington, VA.

Belal, I.E.H.; Al-Owaifeir, A. and Al-Dosari, M. (1995): 'Replacing fish meal with chicken offal silage in commercial Oreochromis niloticus (L.) feed', Aquaculture Research, 26(11), 855-858.

Cruz-Suárez, L.E. (2007): 'Replacement of fish meal with poultry by-product meal in practical diets for Litopenaeus vannamei, and digestibility of the tested ingredients and diets', Aquaculture. 272(1-4), 466-476.

Driehuis, F.; Oude Elferink, S. and Van Wikselaar, P.G. (2001): 'Fermentation characteristics and aerobic stability of grass silage inoculated with Lactobacillus buchneri, with or without homofermentative lactic acid bacteria', Grass and Forage Science. 56(4), 330-343.

Fagbenro, O.A. and Bello-Olusoji, O.A. (1997): 'Preparation, nutrient composition and digestibility of fermented shrimp head silage', Food Chemistry. 60(4), 489-493.

Hashoda, K.P. (2001): 'Changes in microbial population during fermentation of silkworm pupae', Sericologia (France).

Higgs, D.A. (1979): 'Development of practical dry diets for coho salmon using poultry-byproduct meal, feather meal, soybean meal and rapeseed meal as major protein sources', Finfish Nutrition and Fishfeed Technology. Heenemann Verlagsgesellschaft $\mathrm{MbH}$.

Lee, K. (2003): 'Effect of aeration for the probiotic feed production from food wastes by Lactobacillus acidophilus and Saccharomyces cerevisiae', Journal of the Korea Organic Resource Recycling Association. Korea Organic Resource Recycling Association, 11(4), 114-119.

Manual, D. (1984): 'Detroit: Difco Laboratories'.

Minim, V.P.R. (2006): Análise sensorial: estudos com consumidores. Universidade Federal de Viçosa.

Mondal, K.; Kaviraj, A. and Mukhopadhyay, P.K. (2008): 'Evaluation of fermented fish-offal in the formulated diet of the freshwater catfish Heteropneustes fossilis', Aquaculture Research. 39(13), 1443-1449.

Raghunath, M.R. and Gopakumar, K. (2002): 'Trends in production and utilization of fish silage', Journal of Food science and technology. Association of Food Scientists and Technologists, 39(2), 103-110.

Samaddar, A. and Kaviraj, A. (2014): 'Processing of fish offal waste through fermentation utilizing whey as inoculum', International Journal of Recycling of Organic Waste in Agriculture. 3(1), 45

Soltan, M.A. and Tharwat, A.A. (2006): 'Use of fish silage for partial or complete replacement of fish meal in diets of Nile tilapia (Oreochromis niloticus) and African catfish (Clarias gariepinus)', Egyptian J. Nutrition and Feeds, 9(2), 299-314.

Steffens, W. (1994): 'Replacing fish meal with poultry by-product meal in diets for rainbow trout, Oncorhynchus mykiss', Aquaculture. 124(14), 27-34.

Tacon, A.G.J. (1993): 'Feed ingredients for warmwater fish, fish meal and other processed feedstuffs.', FAO Fisheries Circular (FAO). no. 856.

Vidotti, R.M.; Viegas, E.M.M. and Carneiro, D.J. (2003): 'Amino acid composition of processed fish silage using different raw materials', Animal Feed Science and Technology, 199204. doi: 10.1016/S0377-8401(03)00056-7.

Zhao, J.; Dong, Z.; Li, J.; Chen, L.; Bai, Y.; Jia, Y. and Shao, T. (2019): 'Effects of lactic acid bacteria and molasses on fermentation dynamics, structural and nonstructural carbohydrate composition and in vitro ruminal fermentation of rice straw silage', AsianAustralasian journal of animal sciences. Asian-Australasian Association of Animal Production Societies (AAAP), 32(6), 783. 


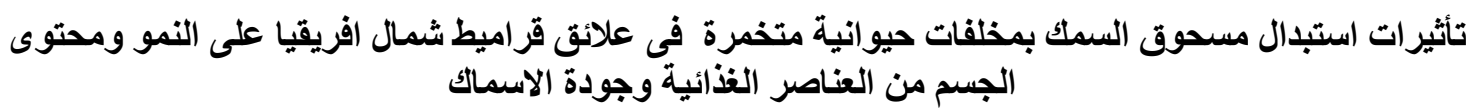

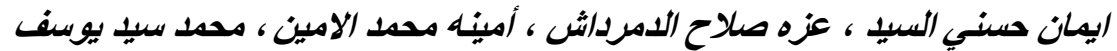

E-mail:Dr.azzasalah@yahoo.com Assiut University web-site: www.aun.edu.eg

أجريت هذه الدراسة لتقييم تأثثير الاستبدال الجزئي لمسحوق السمك بنوعين من الدنتجات الحيو انية المخمرة (نفايات مخلفات الأسماك

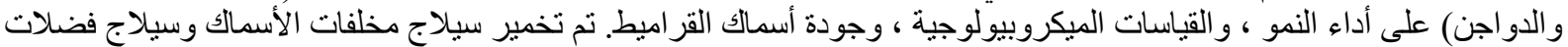

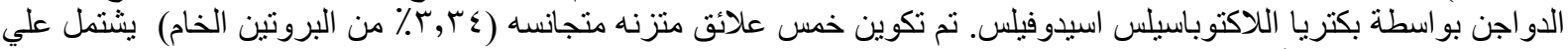

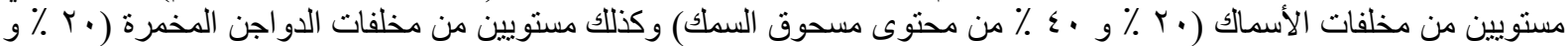

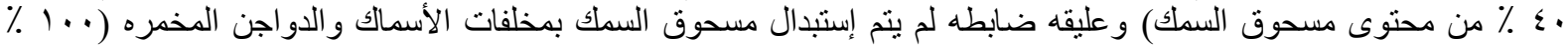

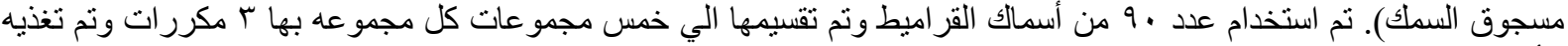

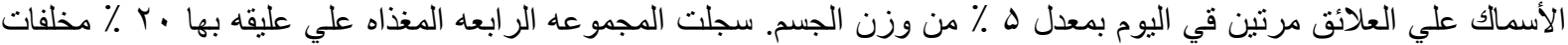

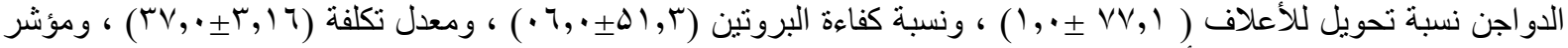

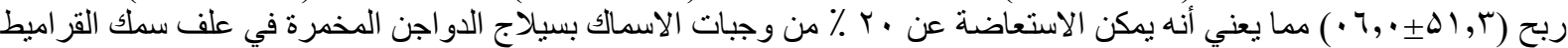

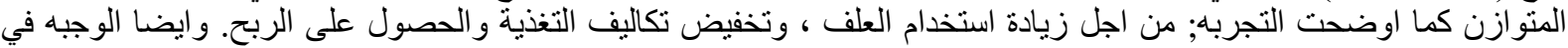

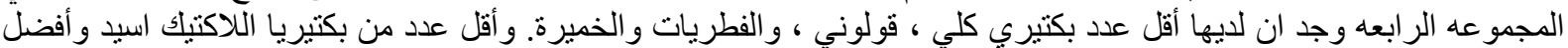

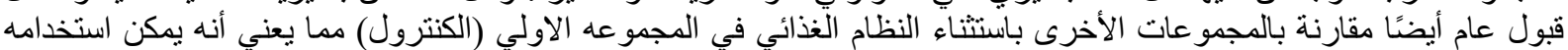
بأمان دون التأثير بشكل كبير على بلى الصحة العامة أو قبول المستهاملك. 